\title{
Mesophilobacter marinus gen. nov., sp. nov.: an Aerobic Coccobacillus Isolated from Seawater
}

\author{
YUKIMASA NISHIMURA,* MASARU KINPARA, AND HIROSHI IIZUKA \\ Institute of Applied Biology, Science University of Tokyo, Noda 278, Japan
}

\begin{abstract}
The name Mesophilobacter marinus gen. nov., sp. nov. is proposed for 11 strains of aerobic, mesophilic, nonmotile, oxidase-positive, penicillin-resistant, moderately halophilic, gram-negative coccobacilli that were isolated from seawater. The genus Mesophilobacter is closely related to the genera Acinetobacter, Moraxella, and Psychrobacter, but the levels of deoxyribonucleic acid relatedness to members of these genera are low. The mesophilobacters have optimal growth temperatures of 33 to $37^{\circ} \mathrm{C}$ and can grow in broth containing $7 \%$ sodium chloride. The ubiquinone system is $Q-8$, and the major cellular fatty acids are $C_{16: 1}, C_{18: 1}$, and $C_{16: 0}$ acids. The guanine-plus-cytosine contents of the deoxyribonucleic acids are 44.0 to 46.9 mol \%. The type strain of this species is strain 14S-4 (= IAM 13185).
\end{abstract}

In a previous paper (7), we reported that the strictly aerobic, nonmotile, gram-negative coccobacilli that were isolated from the seawater of Otsuchi Bay (Iwate Prefecture, Japan) and the Indian Ocean were divided into three groups on the basis of morphological, physiological, and chemotaxonomic characteristics. The members of group 1 were pleomorphic or slightly pleomorphic, cytochrome oxidase positive, resistant to penicillin, and moderately halophilic, and they produced acids from carbohydrates. Their optimal growth temperatures were 31 to $37^{\circ} \mathrm{C}$, their ubiquinone system was $Q-8$, and the guanine-plus-cytosine $(G+C)$ contents of their deoxyribonucleic acids (DNAs) were 40.9 to $46.9 \mathrm{~mol} \%$. The members of group 2 were nonpleomorphic or slightly pleomorphic, cytochrome oxidase positive, and susceptible to penicillin, and they produced no acids from carbohydrates. Their optimal growth temperatures were 27 to $34^{\circ} \mathrm{C}$, their ubiquinone system was $\mathrm{Q}-8$, and the $\mathrm{G}+\mathrm{C}$ contents of their DNAs were 41.3 to $46.4 \mathrm{~mol} \%$.

On the basis of these results and other data, the members of group 1 were classified as a separate genus closely related to the genera Acinetobacter and Moraxella, and the members of group 2 were assigned to the genus Moraxella.

A number of authors have summarized the general phenotypic features of acinetobacters or moraxellas isolated from seawater $(3,5,11)$. However, few detailed taxonomic studies of these organisms are available.

On the basis of phenotypic characteristics and DNA-DNA hybridization tests, we propose a new genus and species, Mesophilobacter marinus, for 11 strains in the above-mentioned group 1.

\section{MATERIALS AND METHODS}

Bacterial strains. We examined 35 strains that were isolated from seawater and were described in a previous study (7), as well as the following reference bacteria: Acinetobacter calcoaceticus type strain IAM 12087 (= ATCC $23055=$ CIP 81.08 = Doudoroff 46), Acinetobacter lwoffii type strain ATCC 15309 (= CIP 64.10), Moraxella lacunata type strain GIFU 3140 (= ATCC 17967 = Morax 260), Moraxella phenylpyruvica type strain ATCC 23333 (Bøvre and Henriksen 2863), Moraxella osloensis type strain CCM 5605 (= ATCC $19976=$ Henriksen A1920), and Psychrobacter immobilis type strain ATCC 43116 (= Juni A351) (4).

\footnotetext{
* Corresponding author.
}

Strain $14 \mathrm{~S}-4$, which was isolated from seawater, is deposited in the culture collection of the Institute of Applied Microbiology (IAM), University of Tokyo, Tokyo, Japan, as type strain IAM 13185 of Mesophilobacter marinus gen. nov., sp. nov.

Cultures and cultivation. The isolates were cultured on marine broth 2216 (Difico Laboratories, Detroit, Mich.), which was used as a basal medium for cell production and for physiological, biochemical, and chemotaxomomic tests. The reference organisms were cultured on heart infusion broth (Nissui Pharmaceutical Co., Ltd., Tokyo, Japan) containing calf serum (GIBCO Laboratories, Grand Island, N.Y.). To isolate DNA, the organisms were grown to the late logarithmic phase by using a rotary shaker $(220 \mathrm{rpm})$ at an appropriate optimum temperature.

Bacteriological procedures. The cellular morphology of isolates was determined with cells grown in marine broth for 3 to $26 \mathrm{~h}$ at $30^{\circ} \mathrm{C}$. The optimal growth temperature was taken to be the growth temperature which gave the highest optical density at $660 \mathrm{~nm}$ after incubation for 5 to $7 \mathrm{~h}$ when a model TN-3 temperature gradient apparatus (Advantic Toyo, Ltd., Tokyo, Japan) was used. The effects of salt concentrations on the growth of the isolates were examined by using nutrient broth $(3.0 \mathrm{~g}$ of beef extract [Difco] and $5.0 \mathrm{~g}$ of Bacto-Peptone [Difco] in 1,000 ml of distilled water, $\mathrm{pH} \mathrm{7.6)}$ and several concentrations of sodium chloride. Nitrate reduction was tested by using marine broth containing $0.1 \%$ $\mathrm{KNO}_{3}$. Oxidation-fermentation was tested by using a complex medium consisting of oxidation-fermentation basal medium prepared with half-strength artificial seawater (7).

Isolation of DNA and DNA-DNA hybridization. Isolation of DNA and DNA-DNA hybridization tests were carried out as described previously (8). Purified DNA was labeled in vitro with $\left[{ }^{3} \mathrm{H}\right]$ deoxycytidine $5^{\prime}$-triphosphate (ammonium salt) by using the nick translation techniques described by Rigby et al. (10) and $\mathrm{a}^{3} \mathrm{H}$ nick translation kit (code TRK.625 and code N.5000A; Amersham International plc, Buckinghamshire, England).

The labeled DNA probe was sheared by sonication for 1 min in $0.1 \times \mathrm{SSC}(1 \times \mathrm{SSC}$ is $0.15 \mathrm{M} \mathrm{NaCl}$ plus $0.015 \mathrm{M}$ trisodium citrate) and was denatured by heating, and then it was poured into a solution containing $25 \%$ sodium dodecyl sulfate and $10 \times$ SSC to give final concentrations of $2 \times$ SSC and $0.1 \%$ sodium dodecyl sulfate and a specific activity of ca. $5.0 \times 10^{3}$ to $1.0 \times 10^{4} \mathrm{cpm} / \mathrm{ml}$. Unlabeled DNA in $2 \times$ SSC was denatured by heating and then trapped on a 
TABLE 1. Homology values and $\mathrm{G}+\mathrm{C}$ contents of DNA preparations

\begin{tabular}{|c|c|c|c|c|c|c|}
\hline \multirow[b]{2}{*}{ Source of unlabeled DNA } & \multicolumn{5}{|c|}{ \% Homology with labeled DNA from: } & \multirow{2}{*}{$\begin{array}{l}\mathrm{G}+\mathrm{C} \text { content } \\
\quad(\mathrm{mol} \%)\end{array}$} \\
\hline & $\begin{array}{l}\text { Strain } \\
14 S-4^{T}\end{array}$ & $\begin{array}{l}\text { Strain } \\
5 S-4\end{array}$ & $\begin{array}{l}P . \text { immobilis } \\
\text { Juni A351 }\end{array}$ & $\begin{array}{l}\text { Moraxella lacunata } \\
\text { GIFU } 3140^{\mathrm{T}}\end{array}$ & $\begin{array}{l}\text { Moraxella osloensis } \\
\quad \text { CCM } 5605^{\mathbf{T}}\end{array}$ & \\
\hline \multicolumn{7}{|l|}{ Group 1 strains } \\
\hline $14 \mathrm{~S}-4^{\mathrm{T}}$ & 100 & 100 & 3 & 2 & 3 & $45.0^{a}$ \\
\hline $5 S-4$ & 100 & 100 & 2 & 3 & 3 & 45.4 \\
\hline $21 S-1$ & 99 & 87 & 6 & 2 & 3 & 45.8 \\
\hline $22 S-8$ & 94 & 77 & 4 & 1 & 4 & 44.6 \\
\hline $22 S-5$ & 81 & 71 & 2 & 1 & 3 & 44.4 \\
\hline $15 S-2$ & 69 & 69 & $\overline{1}$ & 2 & 2 & 44.0 \\
\hline $13 \mathrm{~S}-3$ & 69 & 47 & 6 & 1 & 3 & 46.0 \\
\hline $6 \mathrm{~N}-1$ & 67 & 64 & 4 & 2 & 1 & 46.9 \\
\hline $16 S-2$ & 63 & 49 & 5 & 2 & 2 & 45.8 \\
\hline $4 \mathrm{~S}-1$ & 62 & 50 & 4 & 2 & 1 & 46.1 \\
\hline $17 \mathrm{~S}-7$ & 59 & 45 & 3 & 4 & 6 & 45.3 \\
\hline $1 S-3$ & 54 & 38 & 2 & 2 & 2 & 40.9 \\
\hline $3 \mathrm{~S}-2$ & 46 & 36 & 3 & 1 & 0 & 45.6 \\
\hline $8 S-2$ & 41 & & 2 & 2 & 1 & 45.0 \\
\hline $7 \mathrm{~S}-1$ & 21 & 14 & 2 & 1 & 1 & 46.3 \\
\hline $20 \mathrm{~S}-3$ & 16 & 6 & 2 & 1 & 2 & 45.7 \\
\hline $7 \mathrm{~S}-2$ & 14 & 9 & 2 & 3 & 3 & 42.5 \\
\hline $22 S-6$ & 9 & 7 & 3 & 1 & 1 & 41.3 \\
\hline $18 \mathrm{~S}-1$ & 8 & 9 & 3 & 2 & 1 & 44.4 \\
\hline I14-43 & 4 & 5 & 3 & 3 & 2 & 44.1 \\
\hline \multicolumn{7}{|l|}{ Group 2 strains } \\
\hline $9 S-5$ & 5 & 2 & 79 & 6 & 8 & 43.1 \\
\hline $6 \mathrm{~S}-5$ & 5 & 3 & 38 & 8 & 10 & 46.4 \\
\hline I14-180 & 3 & 3 & 23 & 4 & 5 & 45.9 \\
\hline I13-114 & 4 & 3 & 20 & 5 & 6 & 45.7 \\
\hline $2 S-4$ & 6 & 6 & 3 & 4 & 2 & 44.8 \\
\hline $3 S-7$ & 5 & 3 & 3 & 1 & 1 & 41.3 \\
\hline \multicolumn{7}{|l|}{ Other strains } \\
\hline $11 S-5$ & 14 & 16 & 5 & 3 & & 47.4 \\
\hline $10 \mathrm{~S}-2$ & 9 & 5 & 3 & 2 & & 61.6 \\
\hline I14-38 & 9 & 6 & 2 & 3 & & 59.1 \\
\hline $8 S-1$ & 4 & 4 & 6 & 4 & & 41.1 \\
\hline 19S-1 & 3 & 1 & 1 & 1 & & 58.1 \\
\hline I15-81 & 3 & 3 & 2 & 1 & & 57.0 \\
\hline I13-163 & 2 & 2 & 3 & 1 & & 61.8 \\
\hline I14-124 & 2 & 3 & 1 & 1 & & 51.4 \\
\hline I14-112 & 2 & 1 & 0 & 0 & & 50.5 \\
\hline $\begin{array}{l}\text { A. calcoaceticus IAM } \\
12087^{\mathrm{T}}\left(=\text { ATCC } 23055^{\mathrm{T}}\right)\end{array}$ & 10 & & & 5 & 12 & $41^{b}$ \\
\hline A. lwoffi ATCC $15309^{\mathrm{T}}$ & 6 & & & 8 & 13 & $45.8^{c}$ \\
\hline $\begin{array}{l}\text { Moraxella lacunata GIFU } \\
3140^{\mathrm{T}}\left(=\text { ATCC } 17967^{\mathrm{T}}\right)\end{array}$ & 1 & & & 100 & & 44.1 \\
\hline $\begin{array}{l}\text { Moraxella phenylpyruvica } \\
{\text { ATCC } 23333^{\mathrm{T}}}^{\mathrm{AT}}\end{array}$ & 7 & & & 12 & 10 & $43.0^{d}$ \\
\hline $\begin{array}{l}\text { Moraxella osloensis CCM } \\
5605^{\mathrm{T}}\left(=\text { ATCC } 19976^{\mathrm{T}}\right)\end{array}$ & 6 & & & & 100 & $43.5^{d}$ \\
\hline $\begin{array}{l}\text { P. immobilis Juni A351 } \\
\left(=\text { ATCC } 43116^{\mathrm{T}}\right)\end{array}$ & 3 & 5 & 100 & 3 & 7 & $45^{e}$ \\
\hline
\end{tabular}

a Data from reference 7, as determined from an analysis by high-performance liquid chromatography of hydrolysates of DNA.

$b$ Data from reference 6 .

$c$ Data from reference 8 .

${ }^{d}$ Data from reference 2 .

Data from reference 4.

cellulose nitrate membrane filter (type TM-2; pore size, 0.45 $\mu \mathrm{m}$; Advantic Toyo, Ltd. Tokyo, Japan) by suction, fixed by heating for $3 \mathrm{~h}$ in an $80^{\circ} \mathrm{C}$ oven, and kept in a vacuum desiccator at room temperature until it was reacted with labeled DNA. Portions (1-ml) of a labeled DNA solution were added to unlabeled DNA filters in vials, and the vials were incubated at 60 to $65^{\circ} \mathrm{C}$ for $48 \mathrm{~h}$. After incubation, the vials were cooled to room temperature, and radioactivity levels were counted by using a liquid scintillation counting system (model LSC-700; Aloka Co., Ltd., Tokyo, Japan).
The percentages of relative binding given below are based on averages from three filters.

\section{RESULTS AND DISCUSSION}

Table 1 shows the results of DNA-DNA hybridizations between various marine cocobacilli and six established species. When labeled DNA from isolate $14 \mathrm{~S}-4^{\mathrm{T}}(\mathrm{T}=$ type strain) (group 1) was used as the reference, 11 other group 1 strains showed relatedness values of 54 to $100 \%$. Eight other 
TABLE 2. Differential characteristics of the genera Moraxella, Acinetobacter, Psychrobacter, and Mesophilobacter

\begin{tabular}{|c|c|c|c|c|}
\hline Characteristic & Moraxella $a^{a}$ & Acinetobacter ${ }^{a}$ & Psychrobacter ${ }^{b}$ & Mesophilobacter \\
\hline Cell morphology & Plump rods & $\begin{array}{l}\text { Short or coccoid rods } \\
\text { (pleomorphic) }\end{array}$ & Plump coccobacilli & $\begin{array}{l}\text { Short or coccoid rods } \\
\text { (pleomorphic) }\end{array}$ \\
\hline Oxidase test & $+^{d}$ & - & + & + \\
\hline Acid produced from glucose & - & $\mathrm{D}$ & D & + \\
\hline Indole production & - & - & - & $\mathrm{D}$ \\
\hline Growth at $5^{\circ} \mathrm{C}$ & $(-)$ & + & + & + \\
\hline Growth at $37^{\circ} \mathrm{C}$ & + & + & - & + \\
\hline Growth in $6 \% \mathrm{NaCl}$ & $(-)$ & $\mathrm{D}$ & $(-)^{e}$ & + \\
\hline Penicillin resistance & - & + & - & + \\
\hline Ubiquinone system & $\mathrm{Q}-8^{c}$ & Q-9 ${ }^{c}$ & $\mathrm{Q}-8^{e}$ & Q-8 \\
\hline Major fatty acids: & & & & \\
\hline Type $A\left(C_{18: 1}, C_{16: 0}, C_{16: 1}\right)$ & $+f$ & $+^{f}$ & & \\
\hline Type $B\left(C_{18: 1}, C_{16: 0}, C_{18: 2}\right)$ & $+^{f}$ & & & \\
\hline Type $C\left(\mathrm{C}_{18: 1}, \mathrm{C}_{16: 1}, \mathrm{C}_{18: 2}\right)$ & $+f$ & & & \\
\hline Type D $\left(\mathrm{C}_{18: 1}, \mathrm{C}_{18: 2}, \mathrm{C}_{16: 1}\right)$ & $+^{f}$ & & $+f$ & \\
\hline Type $E\left(C_{18: 1}, C_{17: 1}, C_{16: 1}\right)$ & & & $+^{f}$ & \\
\hline Type $F\left(C_{16-1}, C_{18 \cdot 1}, C_{16: 0}\right)$ & & +8 & & + \\
\hline Optimum temp $\left({ }^{\circ} \mathrm{C}\right)$ & $33-35$ & $30-32$ & 20 & $33-37$ \\
\hline $\mathrm{G}+\mathrm{C}$ content of DNA (mol\%) & $40-47.5$ & $38-47$ & $44-46$ & $44.0-46.9$ \\
\hline Original isolation source & Human & Soil & Pork sausage & Seawater \\
\hline
\end{tabular}

${ }^{a}$ Data from reference 1 .

$b$ Data from reference 4 .

$c$ Data from reference 7

${ }^{d}+$, All strains positive; - , all strains negative; $(-)$, most strains negative; $\mathrm{D}$, different reactions by different strains.

e Nishimura, unpublished data.

${ }^{f}$ Data from reference 9 .

${ }^{g}$ Data from reference 12 .

group 1 strains appeared to be less related to strain $14 \mathrm{~S}-4^{\mathrm{T}}(4$ to $46 \%$ homology). Little relatedness was observed between the group 1 isolate and six group 2 strains, nine unclassified strains, or the strains of six established species used as reference organisms. Similar results were observed when labeled DNA from a second group 1 isolate (strain 5S-4) was used in hybridization comparisons.

When $\boldsymbol{P}$. immobilis Juni A351 $1^{\mathrm{T}}$ DNA was used as the reference DNA, only a single group 2 strain (strain 9S-5) showed a significant level of relatedness (79\%). None of the marine coccobacilli studied showed any significant DNA relatedness to reference DNA prepared from Moraxella lacunata GIFU $3140^{\mathrm{T}}$ or Moraxella osloensis CCM $5605^{\mathrm{T}}$.

From our results, we concluded that 11 group 1 strains that exhibited relatedness values of $59 \%$ or greater should be considered members of the same species. The $\mathrm{G}+\mathrm{C}$ contents of these strains varied from 44.0 to $46.9 \mathrm{~mol} \%$. For these 11 strains, which can be differentiated by using a number of phenotypic markers (Table 2), we propose a new genus and species, Mesophilobacter marinus.

Description of Mesophilobacter gen. nov. Mesophilobacter (Me.so.phi.lo.bac'ter. Gr. n. mesos, middle; Gr. adj. philus, loving; M.L. n. bacter, rod, staff; M.L. masc. n. Mesophilobacter, mesophilic rod). The strains are aerobic, gram negative, nonmotile, nonsporeforming, nonencapsulated, non-acid fast, catalase positive, oxidase positive, nonfermentative, and penicillin resistant. The cells are 0.5 to 0.6 $\mu \mathrm{m}$ in diameter and 1.0 to $2.0 \mu \mathrm{m}$ long. Pleomorphic. A plump form $(0.8$ to 1.0 by 1.5 to $3.0 \mu \mathrm{m})$ and elongated cells (15 $\mu \mathrm{m}$ or more long) occur in young cultures, and coccoid cells ( 0.6 to $0.9 \mu \mathrm{m}$ in diameter) occur in old cultures. All strains grow well at 33 to $37^{\circ} \mathrm{C}$; growth also occurs at $5^{\circ} \mathrm{C}$ but not at $0^{\circ} \mathrm{C}$.

Description of Mesophilobacter marinus sp. nov. Mesophilobacter marinus (ma.ri'nus. L. adj. marinus, of the sea, marine). Nutrient agar colonies are mostly circular but sometimes irregular, smooth, slightly convex, entire, glisten- ing, opaque, and pale yellowish brown. Growth in nutrient broth is moderate and turbid, and a slight sediment is formed.

Litmus milk is unchanged. Some strains produce indole. Hydrogen sulfide is not produced. The methyl red test is positive. The Voges-Proskauer test is negative. Phenylalanine deaminase negative. Hemolysis negative. Some strains are urease and gelatinase positive. Nitrate is reduced to nitrite.

Acids are produced, but no gas is produced from D-ribose, D-glucose, D-fructose, D-mannitol, and cellobiose.

D-Ribose, D-glucose, D-fructose, maltose, sucrose, trehalose, acetate, citrate, succinate, fumarate, malate, and gluconate are assimilated.

Growth occurs in broth containing $7 \%$ salt and on nutrient agar or a modified nutrient agar containing $20.0 \mathrm{~g}$ of $\mathrm{NaCl}$ and $10.0 \mathrm{~g}$ of $\mathrm{MgCl}_{2} \cdot 6 \mathrm{H}_{2} \mathrm{O}(\mathrm{pH} 7.6)$.

The ubiquinone system is Q-8.

The major cellular fatty acids are the even-numbered straight-chain $\mathrm{C}_{16: 1}, \mathrm{C}_{18: 1}$, and $\mathrm{C}_{16: 0}$ acids.

The $\mathrm{G}+\mathrm{C}$ content of the DNA ranges from 44.0 to 46.9 mol\%.

The source of strains is seawater.

The type strain, strain 14S-4 (= IAM 13185), was isolated from Otsuchi Bay (Iwate Prefecture, Japan).

Taxonomic position of Mesophilobacter marinus. Strains of Mesophilobacter marinus resemble the acinetobacters in cell morphology, penicillin resistance, acid production from carbohydrates ( $A$. calcoaceticus), and major cellular fatty acids. They also have properties in common with the moraxellas and the psychrobacters (cytochrome oxidase and ubiquinone type). The $\mathrm{G}+\mathrm{C}$ contents of the DNAs of the mesophilobacters are similar to values reported previously for species in the genera Acinetobacter, Moraxella, and Psychrobacter. Based on these and other characteristics, the mesophilobacters might also be considered members of the family Neisseriaceae. 


\section{ACKNOWLEDGMENTS}

This research was supported in part by a Grant-in-Aid for Scientific Research from the Ministry of Education, Science and Culture of Japan.

\section{LITERATURE CITED}

1. Bøvre, K. 1984. Family VIII. Neisseriaceae, p. 228-307. In N. R. Krieg and J. G. Hold (ed.), Bergey's manual of systematic bacteriology, vol. 1. The Williams \& Wilkins Co., Baltimore.

2. Bøvre, K., M. Fiandt, and W. Szybalski. 1969. DNA base composition of Neisseria, Moraxella, and Acinetobacter, as determined by measurement of bouyant density in $\mathrm{CsCl}$ gradients. Can. J. Microbiol. 15:335-338.

3. Hauxhurt, J. D., M. I. Krichevsky, and R. M. Atlas. 1980 Numerical taxonomy of bacteria from the Gulf of Alaska. J. Gen. Microbiol. 120:131-148.

4. Juni, E., and G. A. Heym. 1986. Psychrobacter immobilis gen. nov., sp. nov.: genospecies composed of gram-negative, aerobic, oxidase-positive coccobacilli. Int. J. Syst. Bacteriol. 36: 338-391.

5. Kaneko, T., M. I. Krichevsky, and R. M. Atlas. 1979. Numerical taxonomy of bacteria from the Beaufort Sea. J. Gen. Microbiol.
110:111-125.

6. Nishimura, Y., and H. Iizuka. 1976. Microbiological studies on petroleum and natural gas. XIII. Identification of the flavin nucleotide-forming bacteria. J. Gen. Appl. Microbiol. 22:79-84.

7. Nishimura, Y., K. Kanbe, and H. Iizuka. 1986. Taxonomic studies of aerobic coccobacilli from seawater. J. Gen. Appl. Microbiol. 32:1-11.

8. Nishimura, Y., M. Kano, T. Ino, H. Iizuka, Y. Kosako, and T. Kaneko. 1987. Deoxyribonucleic acid relationship among the radiation-resistant Acinetobacter and other Acinetobacter. J. Gen. Appl. Microbiol. 33:371-376.

9. Nishimura, Y., H. Yamamoto, and H. lizuka. 1979. Taxonomic studies of Acinetobacter species-cellular fatty acid composition. Z. Allg. Mikrobiol. 19:256-260.

10. Rigby, P. W. J., M. Dieckmann, C. Rhodes, and P. Berg. 1977. Labelling deoxyribonucleic acid to high specific activity in vitro by nick translation with DNA polymerase I. J. Mol. Biol. 113:237-251.

11. Shimidu, U., E. Kaneko, and N. Taga. 1977. Microbiological studies of Tokyo Bay. Microb. Ecol. 3:173-191.

12. Yantzen, E., K. Bryn, T. Bergan, and K. Bøvre. 1975. Gas chromatography of bacterial whole cell methanolysates. Acta Pathol. Microbiol. Scand. Sect. B. 83:569-580. 